\title{
River-ice break-up/freeze-up: a review of climatic drivers, historical trends and future predictions
}

\author{
T.D. PROWSE, B.R. BONSAL, C.R. DUGUAY, M.P. LACROIX \\ Water and Climate Impacts Research Centre, Environment Canada, University of Victoria, PO Box 1700 STN CSC, Victoria, \\ British Columbia V8W 2Y2, Canada \\ E-mail: terry.prowse@ec.gc.ca
}

\begin{abstract}
River ice plays a fundamental role in biological, chemical and physical processes that control freshwater regimes of the cold regions. Moreover, it can have enormous economic implications for river-based developments. All such activities and processes can be modified significantly by any changes to river-ice thickness, composition or event timing and severity. This paper briefly reviews some of the major hydraulic, mechanical and thermodynamic processes controlling river-ice events and how these are influenced by variations in climate. A regional and temporal synthesis is also made of the observed historical trends in river-ice break-up/freeze-up occurrence from the Eurasian and North American cold regions. This involves assessment of several hydroclimatic variables that have influenced past trends and variability in river-ice break-up/freeze-up dates including air-temperature indicators (e.g. seasonal temperature, $0^{\circ} \mathrm{C}$ isotherm dates and various degree-days) and large-scale atmospheric circulation patterns or teleconnections. Implications of future climate change on the timing and severity of river-ice events are presented and discussed in relation to the historical trends. Attention is drawn to the increasing trends towards the occurrence of mid-winter break-up events that can produce especially severe flood conditions but prove to be the most difficult type of event to model and predict.
\end{abstract}

\section{INTRODUCTION}

River ice is one of the major components of the cryosphere and affects an extensive portion of the global hydrologic system, particularly in the Northern Hemisphere where major ice covers develop on $29 \%$, and seasonal ice affects $58 \%$, of the total river length (Bennett and Prowse, in press). It is also an important modifier of numerous biological, chemical and hydrologic processes (Prowse, 2005) and is capable of causing extensive and costly damage to infrastructure (Beltaos, 1995). Because the various forms and processes of river ice are directly controlled by atmospheric fluxes, their spatial and temporal trends can be used as indicators of climate variability and change. Given the broad ecological and economic significance of river ice, scientific concern has been expressed about how future changes in climate might affect river-ice regimes (e.g. Anisimov and others, 2001; Walsh and others, 2005; Wrona and others, 2005).

Unfortunately, much of the information regarding river ice is scattered widely through the literature. Therefore, the objective of this review is to consolidate such information by focusing on four major objectives: to describe how variations in meteorological conditions control the timing and hydrologic severity of river-ice events; to summarize trends of river-ice freeze-up and break-up events throughout the Northern Hemisphere cold regions; to identify the principal linkages between river ice and key meteorological/climatic variables, including atmospheric teleconnections; and to review the methods and results for predicting future river-ice regimes under changing meteorological and climatic conditions. A focus is placed on freeze-up and break-up events which form the subject of a majority of the published literature and can be used further to determine other iceseason characteristics, such as ice duration. Notably, virtually all of the available literature focuses on the Northern Hemisphere, and North America in particular.

\section{TIMING AND SEVERITY OF RIVER-ICE FREEZE-UP/ BREAK-UP EVENTS}

Indications of climate variability are manifested most clearly in river-ice regimes by seasonal and/or interannual variations in ice thickness, ice-cover duration and the timing and hydrologic severity of freeze-up and break-up events. The following two subsections summarize these climate/ river-ice relationships.

\section{Freeze-up}

In general, the timing of river-ice freeze-up is controlled by atmospheric and hydrologic conditions. From an energybalance perspective, it is primarily the summer heat budget of a river and the rate of autumn water-to-atmosphere cooling that lead to initial ice development and the subsequent dynamics of freeze-up (e.g. Prowse, 1995). Under the scenario of a warming climate, for example, increased summer heating and reduced autumn cooling would prolong the period of above-freezing water-flow temperatures and thereby delay the occurrence of river freeze-up. Furthermore, if climatic conditions (e.g. increased summer rainfall) also lead to higher river discharge, freeze-up could be delayed further because of a larger and warmer water volume that must be cooled. An advance (i.e. earlier dates) in the timing of freeze-up would be expected under opposite hydroclimatic conditions.

Climate-induced changes to flow and heat budgets can also have a pronounced effect on the hydrologic severity of freeze-up, as expressed by the initial freeze-up thickness and related water levels (Beltaos and Prowse, 2001; Prowse and Beltaos, 2002). Typically, the initial accumulation thickness at freeze-up depends on whether moving ice floes form a complete ice cover by (a) surface juxtaposition, (b) submergence and accumulation of floes into a thicker ice mass, or (c) collapse of these initial covers into thicker 
accumulations (e.g. Pariset and Hausser, 1961; Beltaos, 1995). In all cases, the thickness and water levels of the freeze-up cover are affected by flow velocity and discharge. Hence, if changes in hydroclimatic conditions lead to higher (lower) river flows late in the autumn, freeze-up ice thicknesses and water levels will increase (decrease) in all but very flat reaches. Similarly, changes in thickness and levels can result from climatic warming or cooling that leads to changes in the temperature and related mechanical strength of the accumulating cover. Warmer temperatures, for example, would be expected to produce an initial freeze-up cover of minimal strength and, all other things being equal, an ice cover more likely to collapse, thicken and produce higher water levels (e.g. Pariset and Hausser 1961; Beltaos, 1983). Thicker accumulations would also affect freeze-up timing since more of the incoming flowing ice would be added to vertical growth of the ice accumulation rather than to an upstream advance of the freeze-up front. Overall, a greater period of time would be required for an ice cover to become hydraulically stable and the freezeup process to be completed.

\section{Break-up}

Similar to freeze-up, the timing and severity of river-ice break-up are sensitive to key climatic and related hydrologic conditions (e.g. Vuglinsky, 2002). In general, the continuum of break-up has been classified into two contrasting types, 'thermal' and 'dynamic' (see review by Gray and Prowse, 1993). These reflect the balancing of forces between those keeping the ice cover intact and stationary (e.g. thickness and strength) and those acting to fracture and dislodge the cover (e.g. river discharge). The respective terms 'overmature' and 'premature' have similarly been used to describe this continuum, but reflect more on the degree of pre-break-up warming (i.e. that leads to reductions in ice resistance and increases in snowmelt runoff). Under constant hydroclimatic conditions, one would expect dynamic or premature events to occur earlier in the season and overmature or thermal events later. Similarly, with variable conditions, an advancement of break-up dates would be anticipated under more intense pre-break-up warming, and the converse. Hence, the general expectation is for earlyseason dynamic events and late-season thermal events, although this can be confounded by the magnitude of winter snow accumulation and subsequent melt, which must be large enough to produce a large floodwave that can effectively 'drive' a dynamic event.

Although these break-up types can to some degree be quantified by their seasonal timing, they are also reflective of hydrologic severity as measured by their associated water levels. The largest increases in stage result from thicker and rougher ice accumulations (as is also the case for freeze-up). The difference in magnitude from freeze-up accumulations is ultimately related to the higher river discharges that typify break-up. These directly affect river stage but also impact ice thickness and the hydraulic roughness of the ice cover, which play additional roles in elevating water levels. In the case of a thermal break-up, the ice cover experiences a protracted period of thinning and mechanical deterioration before being easily flushed away by the prevailing flow. By contrast, dynamic break-ups are characterized by rapid and large runoff leading to fracturing and fragmentation of the ice cover before its mechanical strength or thickness has been significantly reduced. The large discharge accompanied by the resultant thick and hydraulically rough ice accumulations produces the most extreme increases in water levels.

Changes in climate can affect both the resistance and driving forces that determine the above types of break-up. First, in terms of resistance, the critical factors that are controlled by climate include ice competence (that is quantified by the thickness and flexural strength of the ice cover) and the elevation of the pre-break-up ice cover, as largely determined during the preceding freeze-up (i.e. 'freeze-up level' or water level at which the ice cover is first established). Since higher freeze-up levels require greater driving forces to initiate break-up (other factors remaining constant), they lead to the more frequent occurrence of thermal break-ups (e.g. Beltaos and others, 2006b). Notably, however, high-magnitude discharge events could still produce mechanical break-ups under such conditions (Beltaos, 1995, 1997). Hence, the overall effect of increased freeze-up levels would be to produce less frequent but more severe break-up events.

Since resistance to break-up is also controlled by ice thickness and its mechanical strength, changes to winter 'coldness' (which determines ice growth) or the intensity, magnitude and nature of pre-break-up warming (which controls ice thinning and changes in ice competence) can also affect break-up severity. During the pre-break-up period, the efficacy of ice ablation by atmospheric fluxes can further be affected by: (a) the amount of snow that must be ablated first before the underlying ice is exposed; (b) the composition of the ice surface which controls surface albedo and, therefore, rates of radiation-induced ice decay (composition usually being established at freeze-up; see Prowse and Demuth, 1993); and (c) the composition of atmospheric fluxes, shortwave radiation being the most important in inducing changes in mechanical strength (e.g. Ashton, 1985; Prowse and others, 1990a, b).

Changes to the magnitude and intensity of atmospheric fluxes can also directly affect the driving forces controlling break-up (specifically the amount of winter precipitation), which determines the size of the spring snowpack and the rate of snowmelt runoff and subsequent channel discharge. In general, the more rapid the snowmelt, the higher the probability of a dynamic break-up; and the more protracted the melt, the higher the probability of a thermal break-up. The timing of such melt periods is also important. Warmer winters would also mean an increase in the occurrence of mid-winter melt and related break-ups, particularly in the more temperate and maritime ice-covered regions. However, they could also become a new feature of colder interior climates if sufficient mid-winter warming occurs (see below).

\section{HISTORICAL TRENDS}

Records of river-ice conditions are routinely collected in most cold-regions countries, but by numerous agencies and for a variety of purposes. As a result, the types and methods of observations are not uniform, so observations often differ in length and quality. Despite the importance of the hydrologic severity of river-ice events, large-scale regional analyses of such data are virtually non-existent (de Rham, 2006). The same is true for trend analyses of river-ice thickness or composition. By far the most widespread observations are those that relate to the timing of freeze-up and break-up events. Notably, however, there are intercountry and even inter-agency differences in these records. 
For example, some document the initiation of break-up, while others register the state of ice clearance at the end of break-up. This is an important distinction when comparing trends from different sources, given that the entire break-up process can last for up to 4 weeks at a single site (e.g. de Rham, 2006).

There are only a small number of stations in North America that have records longer than 100 years, whereas many Eurasian countries have been archiving river-ice information for up to several centuries. Unfortunately, because of reductions in observing programs beginning around the 1990s in both Russia and Canada (two of the largest cold-regions countries), regional analyses of river-ice trends are statistically more difficult to conduct using the most recent records than they are employing records prior to the end of the 1900s.

The longest records of freshwater-ice dates for the Northern Hemisphere were assembled by Magnuson and others (2000). They found that the most dramatic changes in dates have occurred in the last 150 years, during which freeze-up (break-up) became 5.7 days $(100 \text { years })^{-1}$ later (6.3 days ( 100 years $)^{-1}$ earlier). Interannual variability in dates also noticeably increased after 1950 . The rates of change were noted to correspond to a $\sim 1.2^{\circ} \mathrm{C}(100 \text { years })^{-1}$ change in mean, hemispheric air temperature. Unfortunately, this long-term dataset was largely comprised of lake observations, and the few river sites are too widely spaced to provide a good indication of regional patterns.

Two of the most spatially comprehensive, long-term trend analyses of river-ice freeze-up and break-up dates are provided by Ginzburg and others (1992) and Soldatova (1993), respectively, for the former Soviet Union (FSU). Ice records were summarized for similar hydrologic regions of the European and Asian FSU over the period 1893-1985, and modified to account for any effects of water-resource development (e.g. reservoir impoundment) that could influence the climatic signal (Soldatova, 1992). Although appreciable inter-decadal variability was evident, significant long-term spatial patterns and temporal trends of river-ice freeze-up and break-up dates were identified for the almost 100 year period. The most significant regional trend was for later freeze-up in the European FSU (e.g. upper Volga, Oka and Don) and western Siberia (upper Ob and Irtysh), with rivers such as the Danube, Dnieper, Don, lower Volga and those of the Black Sea region exhibiting an average 2-3 week delay. A weaker but still significant trend to earlier freeze-up dates occurred over portions of the Yenisey and Lena in central and eastern Siberia, respectively (Ginzburg and others, 1992). A similar large-scale spatial pattern was observed for break-up dates (Soldatova, 1993). Break-up had advanced an average of $7-10$ days $(100 \text { years })^{-1}$ in the European FSU and western Siberia. The net effect of this, combined with the delayed freeze-up, was an overall reduction in the ice season by as much as a month (i.e. lower Don River). Again to the contrary, some rivers in central and eastern Siberia (e.g. middle to lower Yenisey and upper Lena) were noted to have an opposing trend: later break-up dates and, hence, an overall expansion of the ice season. Despite the above-noted complexities between the hydroclimatic factors and river-ice event timing, both analyses (Ginzburg and others, 1992; Soldatova, 1993) found that ice-formation and break-up dates correlated well $\left(r^{2}=0.6-0.7\right)$ with those for air temperature in the preceding autumn and spring months, respectively.
Smith (2000) also conducted a shorter-term (54-71 year) analysis of nine major Russian Arctic/sub-arctic rivers but produced some differing results to those of Soldatova (1993). This included several opposing temporal trends for freeze-up and an absence of any statistically significant shifts in breakup timing. Potential inter-decadal variability in ice-event dates and analytical differences in number/location of station data and record length were offered by Prowse and Bonsal (2004) as possible explanations for the differences. Despite finding significant changes in break-up dates, Smith (2000) did determine significant advances for a related break-up observation, 'timing of melt onset', which was suggested as indicating a trend toward a longer period of pre-break-up melt. As described earlier, this would tend to favour less severe 'thermal' break-ups, which are likely to produce high river stages.

Similar to the results for the western portions of the FSU, earlier break-ups have been documented from long-term records $(\sim 100+$ year $)$ for rivers in northern Scandinavia (Torneälven and Torino) and the eastern Baltic Sea (Daugava) (Zachrisson, 1989; Kuusisto and Elo, 2000). Again, parallel to the climatic relationships found for the FSU, Zachrisson (1989) determined the strongest correlation to break-up dates was with spring (April) air temperatures. For one specific period (1870-1950), it was noted that a $3^{\circ} \mathrm{C}$ rise in April temperatures was associated with about a 15 day advance in break-up. Overall, these studies suggest that it is the pre-break-up melt and runoff period that is more important to the timing of break-up, rather than the overall winter severity and maximum ice thickness.

There exist a small number of specific long-term studies of river-ice conditions in North America, all of which show somewhat similar trends over the various hydroclimatic regions. In the temperate maritime climate of southeastern Canada, Williams (1970) discovered that break-up of the Saint John River advanced by approximately the same amount as that of the Torneälven river in Scandinavia over the 1870-1950 period. In the opposite and much colder northwest of North America, studies of the Tanana River in Alaska (1917-2000; Sagarin and Micheli, 2001) and the Yukon River in northwestern Canada (1896-1998; Jasek, 1999) indicated that the average date of break-up had advanced by approximately 5 days per century, although the long-term trend was characterized by a number of interdecadal cycles. In the central continental portions of the country, Rannie (1983) found that the ice season of the Red River was shortened by approximately 2-3 weeks between the 19th and 20th centuries. Specifically, median dates of freeze-up and break-up were 12 and 10 days later and earlier in the 19th than in the 20th century. This corresponded to an increase in autumn and spring temperatures by approximately $2.5^{\circ} \mathrm{C}$ between the two centuries.

The most comprehensive spatial analyses of river-ice trends in North America have been conducted by Zhang and others (2001) and Lacroix and others (2005) using Canadian stations from approximately the second half of the 20th century. Both studies showed a trend towards earlier break-up dates, the most pronounced changes occurring in western and southwestern Canada, and the degree of change increasing towards the latter portion of the century. Lacroix and others (2005) noted that break-up advanced on average by $1-2$ days decade ${ }^{-1}$, the more rapid change being for 30 year climatological intervals near the end of the century. Zhang and others (2001) also found that increasing the 


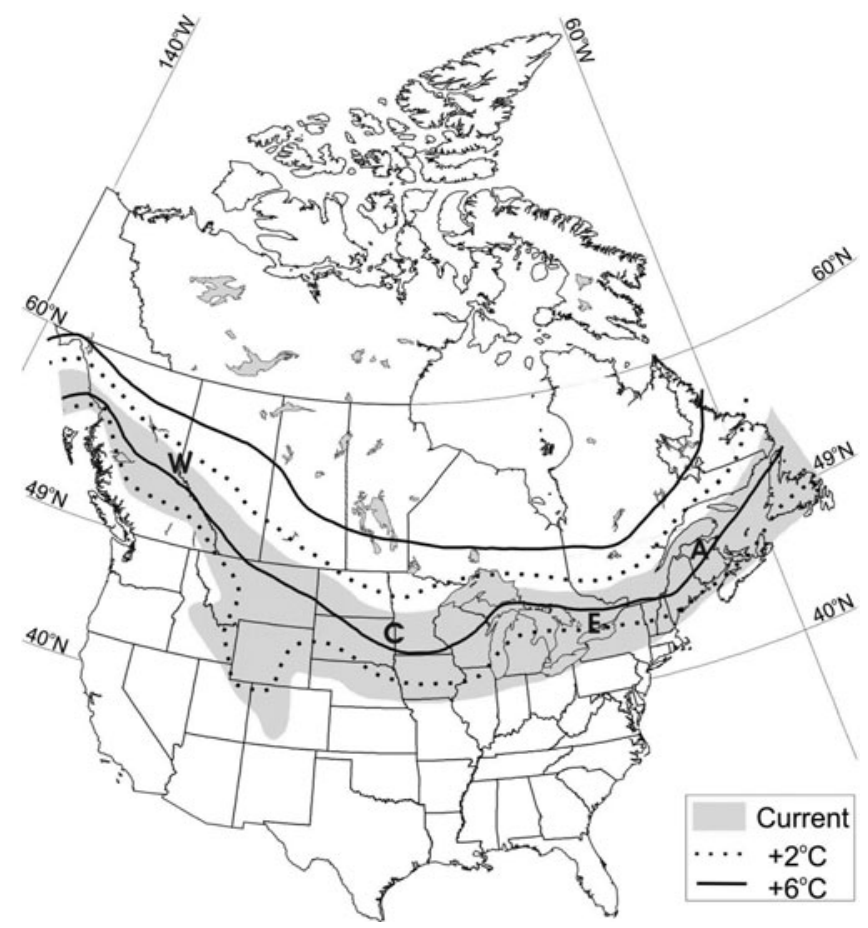

Fig. 1. Map showing the current temperate region (shaded area) and the four subregions used in Prowse and others (2002): western (W), central (C), eastern (E) and Atlantic (A). Projected shifts in the temperate region of North America based on mean winter temperature increases of $2^{\circ} \mathrm{C}$ and $6^{\circ} \mathrm{C}$ are also provided.

period of analysis from 30 to 50 years almost doubled the number of stations showing statistically significant changes. Somewhat different results were found for freeze-up dates, with Zhang and others (2001) noting significant trends to earlier freeze-up dates across the country, whereas Lacroix and others (2005) found that changes in freeze-up ranged from 1 day decade ${ }^{-1}$ later to 0.1 day decade ${ }^{-1}$ earlier. Differences in the results of these two investigations are likely due to the employment of differing intervals and spatial datasets, as noted above for the contrasting FSU results.

As noted by Prowse and Bonsal (2004), a first approximation of river-ice response to climatic changes based on the various cold-regions analyses indicates that a long-term mean increase of $2-3^{\circ} \mathrm{C}$ in autumn and spring air temperature has produced an approximate 10-15 day delay in freeze-up and advance in break-up, respectively. This agrees with the average $0.2^{\circ} \mathrm{Cd}^{-1}$ rate of change in phenological data for numerous lakes and a few rivers estimated by Magnuson and others (2000) for the Northern Hemisphere.

Most analyses of river-ice break-up assume that it is a spring event, although there have been some observations in North America that suggest mid-winter break-ups may be becoming more common (e.g. Beltaos, 2002). Recognizing that most such events are driven by mid-winter warming and are most likely to occur within the southern temperate fringe of the cold regions, Prowse and others (2002) evaluated the frequency of mid-winter warming events for a temperate ice zone (calculated from freezing degree-days) across North America (shaded area in Fig. 1). They found little evidence of any trend along the southern boundary of the temperate zone, but an increasing trend in the number of events through the 20th century at the northern boundary (Fig. 2). This was particularly evident for the western region that has also experienced the most pronounced increase in winter air temperatures over the last 100 years (Zhang and others, 2000). Furthermore, while the Atlantic and central subregions of the zone were devoid of mid-winter events prior to 1950, these areas have experienced a subsequent increase.

\section{RIVER-ICE LINKAGES TO LARGE-SCALE CLIMATE Relationships with Northern Hemisphere temperature}

The preceding review of historical river-ice trends within the Northern Hemisphere has shown that these trends closely match those in associated regional air temperatures. In the context of cryospheric indicators of global change, several investigations have also examined these temperature-ice relationships on much larger temporal and spatial scales. The most notable example is that of Magnuson and others (2000) described earlier. The $1.2^{\circ} \mathrm{C}(100 \text { years })^{-1}$ hemispheric warming that they associated with the long-term advances in freshwater-ice break-up and delays in freeze-up did not, however, occur at a constant rate. Temperature trends over the last 150 year period have actually been quite variable, including widespread increases from 1850 to the 1920s/30s, a slight cooling in the 1940s/50s, and accelerated warming to the present (e.g. Mann and others, 1999; McBean and others, 2005). Many of the $100+$ year break-up/freeze-up records outlined in the previous subsection can reasonably be linked to similar decadal-scale variability in air temperature.

Distinct spatial variability in Northern Hemisphere temperature trends has also been observed, particularly during the second half of the 20th century. For example, the period 1966-95 was associated with pronounced warming over most of Eurasia and western North America, and cooling over eastern North America and Greenland during winter and spring (Serreze and others, 2000). This same pattern in winter and spring temperature trends was observed over Canada by Zhang and others (2000) for the period 1950-98. The spring temperature trends are generally consistent with the previously described large-scale trends in river-ice break-up over the Northern Hemisphere including the pronounced west-to-east gradient over North America (e.g. Zhang and others, 2001; Lacroix and others, 2005). During autumn, North American temperature trends during the last half-century were temporally incoherent, with some areas even showing some degree of cooling (Zhang and others, 2000). This also matches the river-ice freeze-up patterns observed by Lacroix and others (2005). Note that the large-scale winter warming over North America during the last 50 years is also consistent with the trends toward the increased occurrence of mid-winter melt events at the northern boundary of the temperate region defined by Prowse and others (2002; see Fig. 2).

Another approach to assessing the effects of large-scale climate on river-ice break-up/freeze-up timing has involved relating these events to $0^{\circ} \mathrm{C}$ isotherm dates as defined by Bonsal and Prowse (2003). This variable has the advantage of not being constrained by the traditional seasonal definitions of temperature normally used in large-scale climatic studies. Rather, it focuses on the critical period associated with the phase transition of water (which, on average, can vary by 3 months or more between mid- and high latitudes of the Northern Hemisphere). For the period 1950-98, analyses of $0^{\circ} \mathrm{C}$ isotherm timing over Canada revealed a trend toward significantly earlier spring dates in the west (10-20 days), with a gradual weakening to the east 
( $0-5$ days). Autumn $0^{\circ} \mathrm{C}$ isotherms showed little change over the country (Bonsal and Prowse, 2003). These spatial patterns correspond to those for Canadian river-ice breakup/freeze-up summarized previously. Two studies have also examined specific relationships between break-up/freeze-up dates and the timing of spring and autumn $0^{\circ} \mathrm{C}$ isotherm dates for several rivers within Canada. Using the Canadian Ice Data Base, Lacroix and others (2005) determined that break-up dates during the second half of the 20th century were highly correlated to the timing of spring $0^{\circ} \mathrm{C}$ isotherms over most of the country, but these relationships were much weaker and less spatially coherent during autumn. Sitespecific analyses of eight rivers within Canada (1970-95) showed significant correlations $(r>0.66)$ between the spring $0^{\circ} \mathrm{C}$-isotherm and ice-off dates for rivers located in the interior cold-climate regions of the country. Rivers in warmer, maritime climatic zones had lower correlations. While several of these same rivers showed strong correlations between ice-on and autumn $0^{\circ} \mathrm{C}$-isotherm dates, relationships tended to be weaker than spring (D. Milburn and others, unpublished information).

A preliminary investigation into relationships between several intra-seasonal temperature indices and freshwater-ice break-up/freeze-up dates over Canada was carried out by Bonsal and Prowse (unpublished information). These indices included the aforementioned spring and autumn $0^{\circ} \mathrm{C}$ isotherm dates, as well as accumulated freezing/heating degreedays during the cold/warm season. The degree-day indicators were used as a measure of winter severity and summer heating. In the case of rivers, results indicated several significant relationships between the individual temperature indices and ice dates over much of the country. Relationships were strongest in the west and for spring break-up. Furthermore, multiple regressions using all temperature indices explained a higher portion of variance in observed river-ice durations as compared to the individual indices.

\section{Relationships with large-scale circulation patterns}

A large portion of the observed trends and variability in Northern Hemisphere temperature is related to large-scale atmospheric and oceanic oscillations referred to as teleconnections. In particular, El Niño-Southern Oscillation (ENSO) (Rasmusson and Carpenter, 1982), the Pacific North American (PNA) pattern (Wallace and Gutzler, 1981), the Pacific Decadal Oscillation (PDO) (Mantua and others, 1997) and the North Pacific (NP) index (Trenberth and Hurrell, 1994) are closely linked to late-autumn to earlyspring temperatures over much of North America, with strongest relationships in the west. This includes warmer temperatures associated with El Niño events and positive phases of the PNA and PDO that are all representative of a deepened Aleutian low (and the converse) (e.g. Wallace and others, 1995; Bonsal and others, 2001). A notable feature in the Pacific involved a shift toward increased frequencies of a deeper Aleutian low in the mid-1970s (e.g. Trenberth, 1990).

A positive (negative) North Atlantic Oscillation (NAO) is related to colder (warmer) autumn-spring temperatures over eastern North America and warmer (colder) conditions over much of western Europe (Hurrell, 1996). A recent trend toward more positive NAO values is consistent with the winter and spring cooling observed over most of northeastern North America and Greenland. This, along with the Aleutian-low shift in 1976, helps explain the west-to-east gradient in both air temperature and associated river-ice

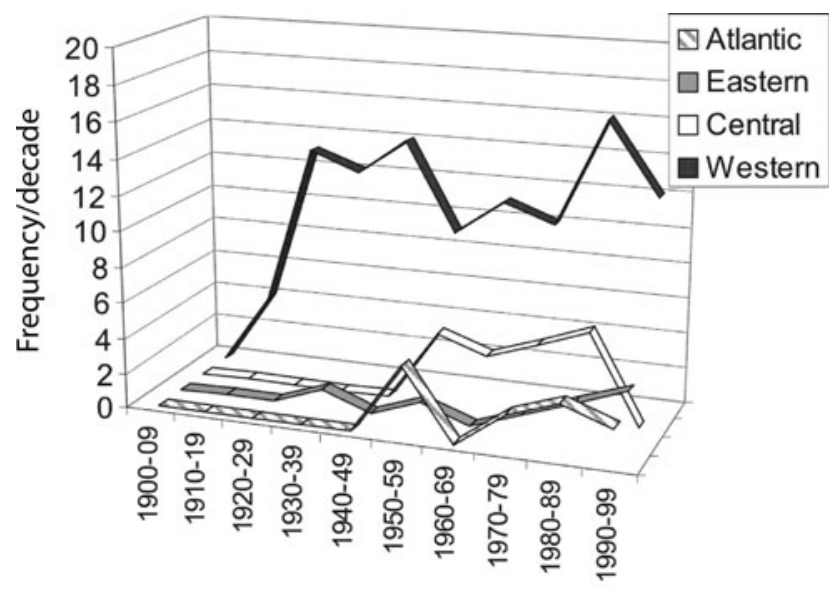

Fig. 2. Frequency of mid-winter temperature events (per decade) for the northern boundary stations in the four regions in Figure 1 (from Prowse and others, 2002).

break-up observed over Canada during the last 50 years. The recently identified Arctic Oscillation (AO) has been associated with the significant trend toward warmer winter and spring temperatures over western North America and most of northern Eurasia during the last 20-30 years (Thompson and Wallace, 1998).

Twentieth-century trends and variability in spring $0^{\circ} \mathrm{C}$ isotherm dates over Canada were found to be related significantly to the NP index over western regions of the country and to the NAO in the east (Bonsal and Prowse, 2003). Shabbar and Bonsal (2004) determined that the frequency and duration of winter warm spells over most of Canada were significantly increased in association with El Niño events as compared to La Niña events. This increase would affect the occurrence of mid-winter thaws and associated break-ups during the winter period.

Given the correspondence between teleconnections and air temperature, a few attempts have been made to relate large-scale oscillations to river-ice durations over various regions of the Northern Hemisphere. Robertson and others (2000) examined the influence of El Niño on 20th-century variations in lake and river-ice cover over the Northern Hemisphere. For break-up, they found that dates were significantly earlier throughout North America, and slightly later (although not significant) over Finland and Russia in association with strong El Niño events. A comprehensive examination of relationships between several teleconnection indices and freshwater-ice break-up/freeze-up dates over Canada was carried out by Bonsal and others (2006). In the case of rivers, results for the period 1950-99 revealed distinct large-scale spatial patterns in these relationships. The Pacific-related indices (PNA, PDO and NP) had the strongest correlations with river-ice durations over much of Canada. In particular, the positive phases of the PNA and PDO, and negative phases of the SOI and NP, were associated with shorter durations consisting of earlier break-ups and later freeze-ups (and vice versa). The relationships were stronger, and covered more of the country during spring break-up, while the freeze-up response was generally weaker and confined to western Canada (e.g. Fig. 3). The composite ENSO findings were similar to the other Pacific indices, with shorter ice durations during $\mathrm{El} \mathrm{Niño}$ and longer durations during La Niña over much of Canada. 

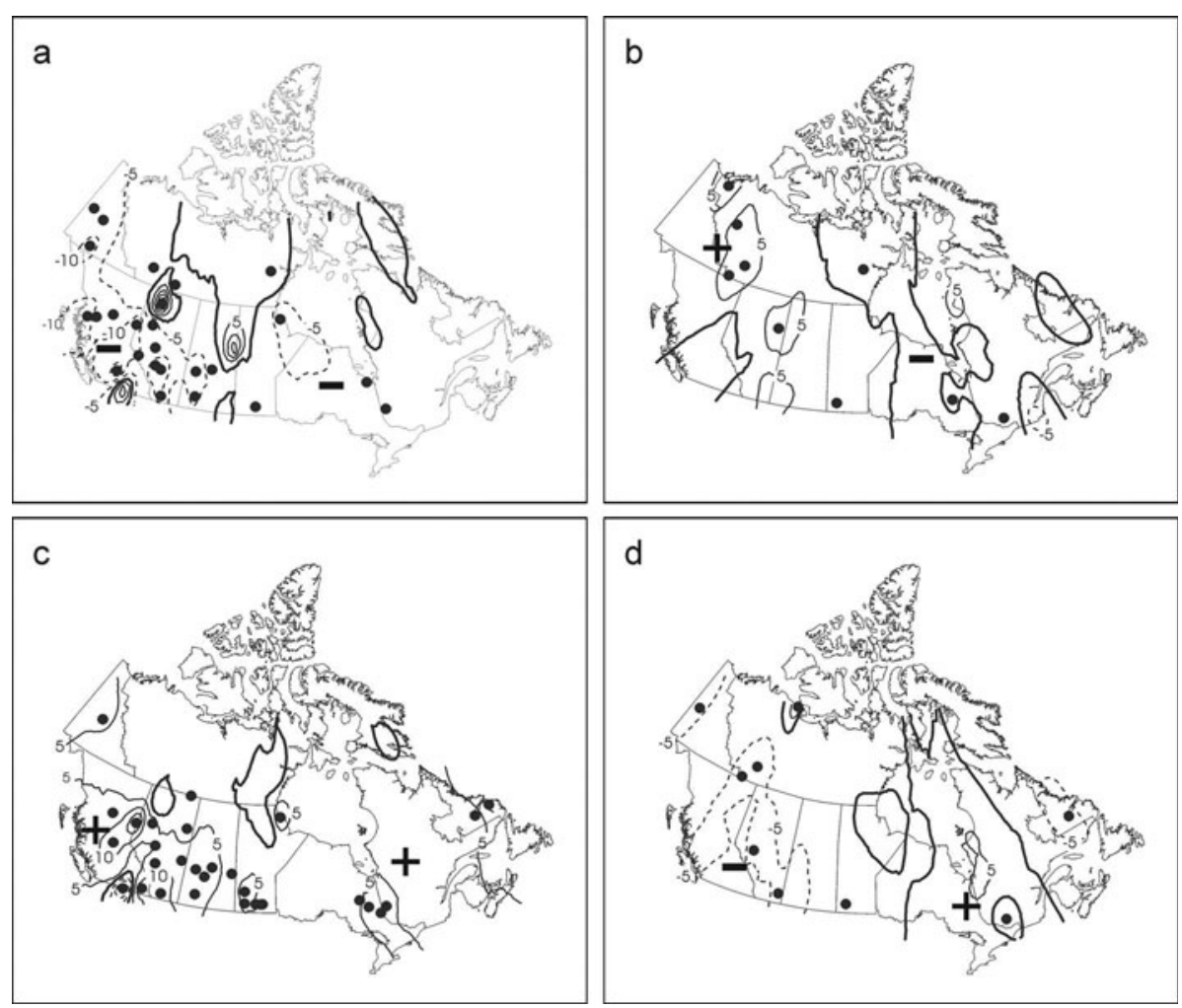

Fig. 3. Composite river-ice break-up and freeze-up anomalies (in days) during positive/negative PNA springs/autumns during the period 1950-99. (a) Positive PNA springs and break-up; (b) positive PNA autumns and freeze-up; (c) negative PNA springs and break-up; and (d) negative PNA autumns and freeze-up. Contour interval is 5 days. Negative values are dashed and the 0.0 contour thickened. Black dots denote river-ice locations with composite anomalies significantly from non-positive PNA (non-negative PNA) springs/autumns at the 5\% level using a Monte Carlo procedure. Plus and minus signs indicate regions with similar large-scale responses (from Bonsal and others, 2006).

\section{FUTURE PROJECTIONS}

At site-specific scales, common methods of predicting riverice break-up initiation stem from a technique originally proposed by Shulyakovskii (1966) in which a relationship is established between the rise in stage above the preceding freeze-up level and the total pre-break-up heat input to the ice cover. Overmature break-ups are represented by high heat inputs and low stage levels, while premature break-ups have lower heat inputs and high stage levels. Unfortunately, relationships between these two terms remain empirical and site-specific (Gray and Prowse, 1993). Therefore, the approach of projecting future changes to river ice taken by most researchers has involved examination of large-scale changes to relevant air-temperature variables such as seasonal temperatures or $0^{\circ} \mathrm{C}$ isotherm dates.

Prowse and others (2002) made some first-order estimates for river-ice conditions at both northern and temperate latitudes of North America. Relying on the average $0.2^{\circ} \mathrm{Cd}^{-1}$ rate of change in phenological break-up dates estimated by Magnuson and others (2000), they approximated that an increase of $3-7^{\circ} \mathrm{C}$ in spring air temperatures by the end of this century (as projected by several General Circulation Models (GCMs); Houghton and others, 2001) would result in a 15-35 day advance in river-ice break-up over northern regions of Canada. In another analysis, Bonsal and others (unpublished information) examined future changes to spring and autumn $0^{\circ} \mathrm{C}$ isotherm dates over Canada (Fig. 4) based on average temperature projections from seven international GCMs for the 30 year period centred on the 2050s (2040-69). The projections were based on monthly temperature changes (with respect to the 1961-90 baseline period) from seven international GCMs using the A2 emission scenario. For spring, $0^{\circ} \mathrm{C}$ isotherm dates were projected to occur considerably earlier over the entire country, with greatest changes near the western and eastern coasts (12-14 days). Changes are less pronounced over northern Canada (approximately $8-10$ days). Autumn is associated with a later occurrence of the $0^{\circ} \mathrm{C}$ isotherms over the entire country. In contrast to spring, the largest changes occur over the north (10-12 days) as compared to the south (around 8 days). Given the close correspondence between $0^{\circ} \mathrm{C}$ isotherm dates and river-ice break-up/freezeup dates outlined previously, the authors hypothesized that by the middle of this century, river-ice durations over most of Canada will be approximately 20 days shorter with respect to the 1961-90 baseline period.

Whether these projected temporal shifts will produce more or less severe break-up events remains in doubt, largely because of the complicating role of precipitation, which has the potential to control both the driving and resisting forces that affect break-up severity (see Prowse and Beltaos, 2002). Another factor that impacts break-up severity involves the strong south-to-north climatic gradient between the headwaters and downstream reaches on most coldregions rivers (e.g. Gray and Prowse, 1993). Future changes to the strength of this climatic gradient will likely alter the severity of break-up. Late-21st-century temperature changes projected for the cold season (October-May) indicate that north-to-south temperature gradients will be reduced over some regions of the Arctic, since higher latitudes will experience greater warming (Prowse and others, 2006; see 

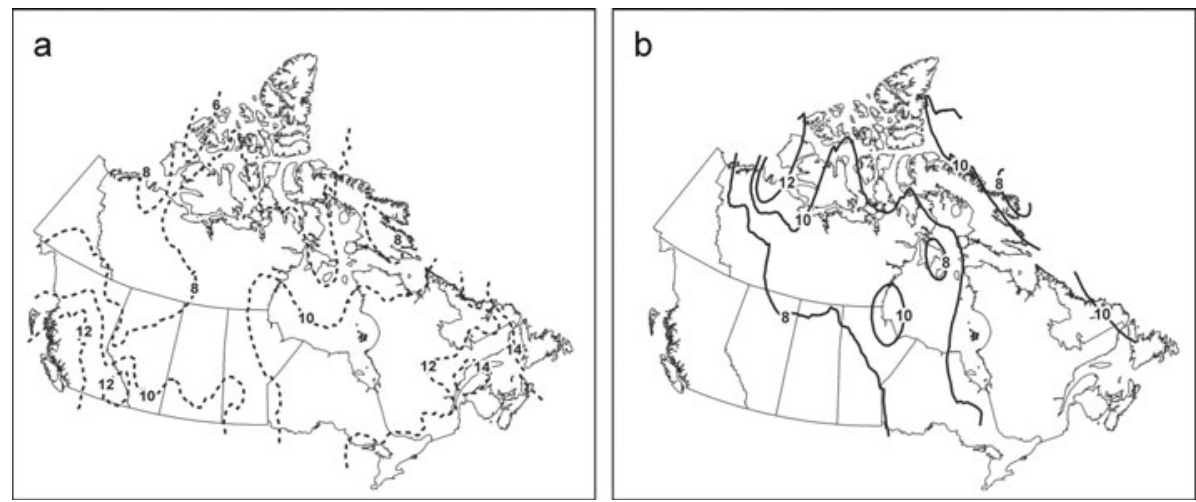

Fig. 4. Projected changes to spring (a) and autumn (b) $0^{\circ} \mathrm{C}$ isotherm dates over Canada for the 30 year period centred on the 2050s. Contour interval is 2 days, with earlier dates represented by dashed lines. (Adapted from Bonsal and others, unpublished information.)

their fig. 3). This will likely impact the severity of future ice break-up including the occurrence of more thermal and less dynamic events. However, Figure $4 a$ indicates that with respect to spring $0^{\circ} \mathrm{C}$ isotherm changes, northern regions of Canada will experience smaller changes as compared to the rest of the country (thus maintaining or increasing the climatic gradient). These discrepancies are likely due to the different temporal resolutions incorporated in the two analyses. The reduction of the temperature gradients in Prowse and others (2006) was based on projected changes to cold-season (October-May) temperatures, while the spring $0^{\circ} \mathrm{C}$-isotherm changes incorporated temperature changes directly related to the timing of the event (which currently varies from March in the south to early June in the north). Since projected temperature changes are forecast to be greater in the cold season (e.g. March) as compared to the warm season (e.g. June), there is a greater projected change to the timing of $0^{\circ} \mathrm{C}$ isotherm dates over more southerly locations. This outlines the importance of examining future climate changes and resultant river-ice impacts at temporal scales appropriate to the processes being considered.

With regard to future mid-winter break-ups, Prowse and others (2002) suggested a significant northward shift of the temperate climate zone that currently experiences these events (see Fig. 1). These shifts are based on a $2{ }^{\circ} \mathrm{C}$ and $6{ }^{\circ} \mathrm{C}$ warming in winter temperatures over the temperate region as estimated from several GCM projections (Houghton and others, 2001). The northward movement to these boundaries is significant since rivers that currently do not experience mid-winter warming events will be susceptible to river-ice break-ups which could produce dramatic impacts on the hydro-ecology of these river systems. A site-specific analysis of future climatic effects (using the Canadian CGCM2 model) on ice-jam occurrence in the Peace-Athabasca Delta of Canada (Beltaos and others, 2006a) revealed that by the end of this century the ice season will be reduced by 2-4 weeks and ice covers will be slightly thinner. In addition, the Peace River basin is projected to experience more frequent and sustained mid-winter thaws. This translates into fewer dynamic river-ice break-ups in the future.

Given that large-scale teleconnections have been shown to influence air temperature and associated river-ice characteristics over much of the Northern Hemisphere, knowledge of future changes in the frequency and magnitude of these oscillations could provide insight into future river-ice regimes. At present, however, the effects of climate change on large-scale teleconnection patterns remain uncertain due to the lack of agreement concerning the future frequency and structure of atmospheric and oceanic modes among the various climate models (Houghton and others, 2001). For example, with respect to ENSO, certain models have suggested that El Niño-type patterns will become more frequent in a warmer climate (e.g. Timmermann and others, 1999). However, investigations using other GCMs revealed no significant changes to future ENSO frequency or amplitude (Zelle and others, 2005), and even a reduction in the amplitude of these events (Meehl and others, 2006). Because ENSO significantly affects climate over many regions of the Northern Hemisphere and is often associated with variations in other Pacific-related teleconnections, such as the PDO and PNA, knowledge of its future occurrence would assist in projecting regional changes to future river-ice duration and severity. The majority of climate-change investigations have indicated increased occurrence in the positive phases of $\mathrm{AO} / \mathrm{NAO}$ in association with future warming (e.g. Rind and others, 2005). This would result in continued warming over western North America and northern Eurasia, and cooling over northeastern North America and the North Atlantic.

\section{SUMMARY AND RECOMMENDATIONS}

In conducting this review of literature dealing with river ice and climate, it became apparent that the analyses of historical trends have often produced confounding spatial and temporal results. In addition to the complications that arise from climate variability (e.g. inter-decadal fluctuations), other factors such as varying study-period intervals, spatial coverage and/or number of stations used for analysis have also contributed to the confusion. Hence, it is recommended that future assessments consider: more explicitly the variations in climate that have occurred over the period of analysis; the use of the longest period of available records with requisite spatial coverage of reporting stations; and non-linear interpretations of the data. In reference to number of stations and length of records, however, it may be that because of extensive closure of observing stations in the 1990s (e.g. Lacroix and others, 2005), the best interval for trend analysis has already passed. This is exceedingly unfortunate given that the rates of change in some river-ice characteristics, such as break-up timing, seem to have accelerated in later years (probably 
linked to the increased levels of atmospheric warming in cold regions) and are likely to change even more dramatically in the future. Without a robust observing network, it will be difficult to monitor the effects of future climate change/ variability or to validate predictive models. Apart from a reinstatement of observing stations, the only other method for monitoring river-ice changes would be remote sensing. Advancements in sensors offer the possibility of moving beyond the simple detection of trends in event dates to the assessment of severity indices (e.g. extent of flooding).

The intercomparison of river-ice trends from different agencies and countries is also confounded by the type of observation data employed in the analyses (e.g. Catchpole and Moodie, 1974). Although development of a completely coordinated observation program for river ice is unlikely (see, e.g., Prowse, 1990), subsequent interpretations need to recognize that differing definitions of critical river-ice characteristics could have been used (e.g. timing of breakup, the components of which can span several weeks). Moreover, it is recommended that the trend analysis of climate/river-ice relationships be extended beyond simple dates of occurrence to include intervals between different 'event' components, such as the initiation of pre-break-up melt and final ice clearance, which can provide more useful data about conditions that control the hydrologic severity of the event. Furthermore, additional work should focus on trends in ice-cover thickness and duration (the period between freeze-up and break-up) that are so important to many freshwater processes and factors that control the type and availability of transportation in coldregions countries.

Lastly, it appears from the review that predictions of riverice response to variations in atmospheric conditions remain empirical and largely site-specific. As a result, sufficiently robust physically based models are not available for predicting large-scale responses to climate change/variability, and modelling of future conditions has had to rely on proxies such as $0^{\circ} \mathrm{C}$ isotherms. More research needs to be directed towards the development of physically based riverice models that effectively couple with hydrologic-runoff and atmospheric-flux models. This work is a prerequisite to being able ultimately to employ data from GCMs/RCMs (Regional Climate Models) for future climate prediction.

\section{ACKNOWLEDGEMENTS}

Funding for this scientific review was provided by Environment Canada, the Water and Climate Impacts Research Centre, University of Victoria, and the Natural Sciences and Engineering Research Council of Canada. Thanks are due to the two anonymous reviewers for their valuable comments and to the scientific editor $M$. Jeffries.

\section{REFERENCES}

Anisimov, O. and 6 others. 2001. Polar regions (Arctic and Antarctic). In McCarthy, J.J., O.F. Canziani, N.A. Leary, D.J. Dokken and K.S. White, eds. Climate change 2001: impacts, adaptation, and vulnerability. Contribution of Working Group Il to the Third Assessment Report of the Intergovernmental Panel on Climate Change. Cambridge, etc., Cambridge University Press, 801-841.

Ashton, G.D. 1985. Deterioration of floating ice covers. J. Energy Resour. Technol. ASME, 107(2), 177-182.
Beltaos, S. 1983. River ice jams: theory, case studies, and applications. ASCE J. Hydraul. Eng., 109(10), 1338-1359.

Beltaos, S. 1995. River ice jams. Highlands Ranch, CO, Water Resources Publications.

Beltaos, S. 1997. Onset of river ice breakup. Cold Reg. Sci. Technol., 25(3), 183-196.

Beltaos, S. 2002. Effects of climate on mid-winter ice jams. Hydrol. Process., 16(4), 789-804.

Beltaos, S. and T.D. Prowse. 2001. Climate impacts on extreme icejam events in Canadian rivers. Hydrol. Sci. J., 46(1), 157-181.

Beltaos, S. and 6 others. 2006a. Climatic effects on ice-jam flooding of the Peace-Athabasca Delta. Hydrol. Process., 20(19), 4031-4050.

Beltaos, S., T.D. Prowse and T. Carter. 2006b. Ice regime of the lower Peace River and ice-jam flooding of the Peace-Athabasca Delta. Hydrol. Process., 20(19), 4009-4029.

Bennett, K. and T.D. Prowse. In press. Defining the geography of ice-covered rivers. Burlington, Ont., Environment Canada. National Water Research Institute.

Bonsal, B.R. and T.D. Prowse. 2003. Trends and variability in spring and autumn $0{ }^{\circ} \mathrm{C}$-isotherm dates over Canada. Climatic Change, 57(3), 341-358.

Bonsal, B.R., A. Shabbar and K. Higuchi. 2001. Impacts of low frequency variability modes on Canadian winter temperature. Int. J. Climatol., 21(1), 95-108.

Bonsal, B.R., T.D. Prowse, C.R. Duguay and M.P. Lacroix. 2006. Impacts of large-scale teleconnections on freshwater-ice break-up/freeze-up dates over Canada. J. Hydrol., 330(1-2), 340-353.

Catchpole, A.J.W. and D.W. Moodie. 1974. Changes in the Canadian definitions of break-up and freeze-up. Atmosphere, 12(1), 133-138.

de Rham, L. 2006. Spatial and temporal variation of river-ice breakup, Mackenzie River basin, Canada. (MSc thesis, University of Victoria, Canada.)

Ginzburg, B.M., K.N. Polyakova and I.I. Soldatova. 1992. Secular changes in dates of ice formation on rivers and their relationship with climate change. Sov. Meteorol. Hydrol., 12, $57-64$

Gray, D.M. and T.D. Prowse. 1993. Snow and floating ice. In Maidment, D.R., ed. Handbook of hydrology. Toronto, Ont., McGraw-Hill Inc., 7.1-7.58.

Houghton, J.T. and 7 others, eds. 2001. Climate change 2001: the scientific basis. Contribution of Working Group I to the Third Assessment Report of the Intergovernmental Panel on Climate Change. Cambridge, etc., Cambridge University Press.

Hurrell, J.W. 1996. Influence of variations in extratropical wintertime teleconnections on Northern Hemisphere temperature. Geophys. Res. Lett., 23(6), 665-668.

Jasek, M.J. 1999. 1998 break-up and flood on the Yukon River at Dawson - did El Niño and climate change play a role? In Shen, H.T., ed. Ice in Surface Waters: Proceedings of the 14th International Symposium on Ice, 27-31 July 1998, Potsdam, New York, USA. Rotterdam, A.A. Balkema, 761-768.

Kuusisto, E. and A.-R. Elo. 2000. Lake and river ice variables as climate indicators in Northern Europe. Verh. Int. Ver. Theor. Angew. Limnol. [Stuttgart], 27, 2761-2764.

Lacroix, M., T.D. Prowse, B. Bonsal, C. Duguay and P. Ménard. 2005. River ice trends in Canada. In Proceedings of the 13th Workshop on the Hydraulics of Ice Covered Rivers, 1516 September 2005, Hanover, NH, USA. Ottawa, Ont., Canadian Geophysical Union. Committee on River Ice Processes and the Environment, 41-54. CD-ROM.

Magnuson, J.J. and 13 others. 2000. Historical trends in lake and river ice cover in the Northern Hemisphere. Science, 289(5485), 1743-1746.

Mann, M.E., R.S. Bradley and M.K. Hughes. 1999. Northern Hemisphere temperatures during the past millennium: inferences, uncertainties and limitations. Geophys. Res. Lett., 26(6), 759-762. 
Mantua, N.J., S.R. Hare, Y. Zhang, J.M. Wallace and R.C. Francis. 1997. A Pacific interdecadal climate oscillation with impacts on salmon production. Bull. Am. Meteorol. Soc., 78(6), 1069-1079.

McBean, G. and 9 others. 2005. Arctic climate: past and present. In Arctic Climate Impact Assessment, Arctic climate impact assessment: scientific report. Cambridge, etc., Cambridge University Press, 22-60.

Meehl, G.A., H. Teng and G. Branstator. 2006. Future changes of EI Niño in two global coupled climate models. Climate Dyn., 26(6), 549-566.

Pariset, E. and R. Hausser. 1961. Formation and evolution of ice covers on rivers. Trans. Eng. Inst. Can., 5(1), 41-49.

Prowse, T.D. 1990. Guidelines for river ice data collection programs. In Beltaos, S., R. Gerard, S. Petryk and T.D. Prowse, eds. Working Group on River Ice Jams: Field Studies and Research Needs. Saskatoon, Sask., Environment Canada. National Hydrology Research Institute, 1-36. (NHRI Science Report 2.)

Prowse, T.D. 1995. River ice processes. In Beltaos, S., ed. River ice jams. Highlands Ranch, CO, Water Resources Publications.

Prowse, T.D. 2005. River-ice hydrology. In Anderson, M.G., ed. Encyclopedia of hydrological sciences, Vol. 4. Chichester, John Wiley \& Sons, 2657-2677.

Prowse, T.D. and S. Beltaos. 2002. Climatic control of river-ice hydrology: a review. Hydrol. Process., 16(4), 805-822.

Prowse, T.D. and B.R. Bonsal. 2004. Historical trends in river-ice break-up: a review. Nord. Hydrol., 35(4), 281-293.

Prowse, T.D. and M.N. Demuth. 1993. Strength variability of major river-ice types. Nord. Hydrol., 24(2-3), 169-182.

Prowse, T.D., M.N. Demuth and H.A.M. Chew. 1990a. Changes in the flexural strength of ice under radiation decay. Nord. Hydrol., 21(4-5), 341-354.

Prowse, T.D., M.N. Demuth and H.A.M. Chew. 1990b. The deterioration of freshwater ice due to radiation decay. J. Hydraul. Res., 28(6), 685-697.

Prowse, T.D., B.R. Bonsal, M.P. Lacroix and S. Beltaos. 2002. Trends in river-ice breakup and related temperature controls. In Squire, V.A. and P.J. Langhorne, eds. Ice in the Environment: Proceedings of the 16th IAHR Conference on Sea Ice Processes, 2-6 December 2002, Dunedin, New Zealand, Vol. 3. Dunedin, International Association of Hydraulic Engineering and Research, 64-71.

Prowse, T.D. and 6 others. 2006. Climate change effects on hydroecology of arctic freshwater ecosystems. Ambio, 35(7), 347-358

Rannie, W.F. 1983. Break-up and freeze-up of the Red River at Winnipeg, Manitoba, Canada, in the 19th century and some climatic implications. Climatic Change, 5(3), 283-296.

Rasmusson, E.M. and T.H. Carpenter. 1982. Variations in tropical sea surface temperature and surface wind fields associated with the Southern Oscillation/El Niño. Mon. Weather Rev., 110(5), 354-384.

Rind, D., J. Perlwitz and P. Lonergan. 2005. AO/NAO response to climate change: 1 . Respective influences of stratospheric and tropospheric climate changes. J. Geophys. Res., 110(D12), D12107. (10.1029/2004JD005103.)

Robertson, D.M., R.A. Ragotzkie and J.J. Magnuson. 2000. Lake ice records used to detect historical and future climatic changes. Climatic Change, 21(4), 407-427.

Sagarin, R. and F. Micheli. 2001. Climate change in nontraditional data sets. Science, 294(5543), 811
Serreze, M.C. and 9 others. 2000. Observational evidence of recent change in the northern high-latitude environment. Climatic Change, 46(2), 159-207.

Shabbar, A. and B.R. Bonsal. 2004. Association between lowfrequency variability modes and winter temperature extremes in Canada. Atmos.-Ocean, 42(2), 127-140.

Shulyakovskii, L.G., ed. 1966. Manual of forecasting ice formation for rivers and inland lakes. Leningrad, Gidrometeorologicheskoe Izdatel'stvo [1963]. Jerusalem, Israel Program for Scientific Translations.

Smith, L.C. 2000. Trends in Russian Arctic river-ice formation and breakup, 1917 to 1994. Phys. Geogr., 21(1), 46-56.

Soldatova, I.I. 1992. Causes of variability of ice appearance dates in the lower reaches of the Volga. Sov. Meteorol. Hydrol. 2, 62-66.

Soldatova, I.I. 1993. Secular variations in river breakup dates and their relation to climate changes. Russ. Meteorol. Hydrol., 9, 70-76.

Thompson, D.W.J. and J.W. Wallace. 1998. The Arctic Oscillation signature in the wintertime geopotential height and temperature fields. Geophys. Res. Lett., 25(9), 1297-1300.

Timmermann, A., J. Oberhuber, A. Bacher, M. Esch, M. Latif and E. Roeckner. 1999. Increased El Niño frequency in a climate model forced by future greenhouse warming. Nature, 398(6729), 694-697.

Trenberth, K.E. 1990. Recent observed interdecadal climate changes in the Northern Hemisphere. Bull. Am. Meteorol. Soc., 71(7), 988-993.

Trenberth, K.E. and J.W. Hurrell. 1994. Decadal atmosphere-ocean variations in the Pacific. Climate Dyn., 9(6), 303-319.

Vuglinsky, V.S. 2002. Peculiarities of ice events in Russian Arctic rivers. Hydrol. Process., 16(4), 905-913.

Wallace, J.M. and D.S. Gutzler. 1981. Teleconnections in the geopotential height field during the Northern Hemisphere winter. Mon. Weather Rev., 109(4), 784-812.

Wallace, J.M., Y. Zhang and J.A. Renwick. 1995. Dynamic contribution to hemispheric mean temperature trends. Science, 270(5237), 780-783.

Walsh, J.E. and 11 others. 2005. Cryosphere and hydrology. In Arctic Climate Impact Assessment, Arctic climate impact assessment: scientific report. Cambridge, etc., Cambridge University Press, 183-242.

Williams, G.P. 1970. A note on the break-up of lakes and rivers as indicators of climate change. Atmosphere, 8(1), 23-24.

Wrona, F.J., T.D. Prowse and J.D. Reist. 2005. Freshwater ecosystems and fisheries. In Arctic Climate Impact Assessment, Arctic climate impact assessment: scientific report. Cambridge, etc., Cambridge University Press, 353-452.

Zachrisson, G. 1989. Climate variation and ice conditions in the River Torneälven. In Proceedings of the Conference on Climate and Water, 11-15 September 1989, Helsinki, Finland, Vol. 1. Helsinki, Academy of Finland, 353-364.

Zelle, H., G.J. van Oldenborgh, G. Burgers and H. Dijkstra. 2005. El Niño and greenhouse warming: results from ensemble simulations with the NCAR CCSM. J. Climate, 18(22), 4669-4683.

Zhang, X., L.A. Vincent, W.D. Hogg and A. Niitsoo. 2000. Temperature and precipitation trends in Canada during the 20th century. Atmos.-Ocean, 38(3), 395-429.

Zhang, X., K.D. Harvey, W.D. Hogg and T.R. Yuzyk. 2001. Trends in Canadian streamflow. Water Resour. Res., 37(4), 987-999. 